\title{
The Bletia catenulata ornamental orchid is self-compatible but pollinator-dependent for reproduction ${ }^{1}$
}

\author{
Vespasiano Borges de Paiva $\mathrm{Neto}^{2}$, Ana Paula Mezoni Correa², \\ Fábio de Barros ${ }^{3}$, Daly Roxana Castro Padilha ${ }^{2}$, Monica Cristina Rezende Zuffo Borges ${ }^{2}$
}

\section{RESUMO}

A orquídea ornamental Bletia catenulata é autocompatível, mas dependente de polinizador para reprodução

Bletia catenulata é uma orquídea nativa do Brasil, cujas populações têm sofrido coleta predatória. Objetivando conhecer aspectos da biologia reprodutiva e sua relação com a germinação de sementes, diferentes tipos de polinização foram realizados em flores de plantas cultivadas em estufa agrícola. A polinização cruzada e a autopolinização manuais resultaram em altos percentuais de frutificação (76,7-86,7 \%), sendo de apenas 26,7 \% na polinização natural, na qual a ausência de polinizadores, por isolamento das flores, resultou na ausência de frutos. A germinação in vitro de sementes de todos os frutos resultantes das diferentes polinizações foi baixa, sendo $8,6 \%$ o maior valor percentual de protocormos obtidos. Portanto, B. catenulata é autocompatível, gerando sementes viáveis, mas dependente de polinizador para reprodução sexuada.

PALAVRAS-CHAVE: Germinação in vitro; aclimatização; Cerrado.

\section{INTRODUCTION}

Bletia Ruiz \& Pav. is a neotropical orchid genus consisting of about 40 species (Brown 2005). However, in Brazil, only two species have been registered (Barros et al. 2015).

Bletia catenulata Ruiz \& Pav. is a common species in the Brazilian Savannah, Amazonia and Atlantic Forest, being also found in the seashore of the Rio de Janeiro State, at the Massambaba sandbank (Cepemar 2004).

Some authors reported that $B$. catenulata was found in different Brazilian States, such as Tocantins and Maranhão (Silva et al. 1995), Minas Gerais (Araújo et al. 2002), Distrito Federal (Batista et al. 2005) and São Paulo (Ferreira et al. 2010), and also in other countries, such as Bolivia (Vásquez et

\section{ABSTRACT}

Bletia catenulata is a native Brazilian orchid whose populations have suffered from predatory collection. Aiming at elucidating aspects of its reproductive biology and the relation with seed germination, pollination tests were carried out in flowers of plants cultivated in a greenhouse. Manual cross and self-pollination resulted in high percentage of fructification (76.7-86.7 \%), being only $26.7 \%$ for natural pollination, in which the absence of pollinators, due to flower isolation, resulted in absence of fruits. In vitro seed germination for all fruits from the different pollination processes was low, being $8.6 \%$ the highest percentage for protocorms. Thus, $B$. catenulata is selfcompatible, resulting in viable seeds, but pollinator-dependent for sexual reproduction.

KEY-WORDS: In vitro germination; acclimatization; Brazilian Savannah.

al. 2003) and Paraguay (Schinini 2010). We have recently identified this species in the Mato Grosso do Sul State, Brazil.

The distribution of Bletia specimens is determined by factors such as the degree of disturbance of their environment, adaptability of the species and diversity of morphotypes of the available mycorrhizal fungus, which is associated with their dispersibility (Beltrán-Nambo et al. 2012), among others.

In the northeast region of the Mato Grosso do Sul State, B. catenulata was found in four different sites, always with low frequency. In some sites, it is exposed to environments that undergo human disturbance. In addition, this orchid has terrestrial habits, superficial roots and often occurs near watercourses.

1. Manuscript received in Nov./2015 and accepted for publication in Dec./2015 (http://dx.doi.org/10.1590/1983-40632015v4538410).

2. Universidade Federal de Mato Grosso do Sul, Chapadão do Sul, MS, Brasil.E-mails: vespasiano.paiva@terra.com.br, ana.mezoni@hotmail.com, daly.padilha@ufms.br,monicazuffo@terra.com.br.

3. Instituto de Botânica, Núcleo de Pesquisa Orquidário do Estado, São Paulo, SP, Brasil.E-mail: fdebarros@terra.com.br. 
Plant collection and environmental disturbance have threatened the species, intensifying its risk of extinction. Swarts \& Dixon (2009) consider that orchids are primarily threatened by anthropogenic causes, such as habitat destruction, modification and fragmentation, or even over-collection.

Dressler (1968) stated that Bletia flowers are adapted to bee pollination. Self-pollination is frequent in B. campanulata, B. macristhmochila, $B$. purpurea and $B$. urbana, and nearly universal in $B$. rosea. Yet, observations of $B$. campanulata and $B$. purpurea indicate that many plants are facultative autogamous, according to the plant condition and probably to the habitat condition (Dressler 1968). Other plants, sometimes in the same populations, are always autogamous. However, except for the fact that some authors have reported Xylocopa sp. as the pollinator of B. catenulata (Dodson 1962, Van der Cingel 2001), little information related to floral and reproductive biology and no information on seed germination of this species are found in the literature.

Most orchids are self-compatible (Van der Pij1 \& Dodson 1966). However, spontaneous selfpollination tends to be avoided by the presence of some floral mechanisms (Van der Pijl \& Dodson 1966, Catling \& Catling 1991). Additionally, orchids tend to produce more viable seeds after cross-pollination (Stort 1983 and 1986, Smidt et al. 2006). Pollination carried out under experimental conditions also promotes increased fruit production in many Orchidaceae species, when compared with populations in the natural environment (Pansarin 2003, Mickeliunas et al. 2006, Storti et al. 2011). In their habitat, herbivory and fruit and seed predation can negatively influence its reproductive success.

The study of orchid reproductive biology is essential for propagation and breeding. In general, seed viability tests are carried out by using tetrazolium (Suzuki et al. 2012), fluorescent diacetate staining (Chen et al. 2015) and/or in vitro asymbiotic germination (Suzuki et al. 2012, Chen et al. 2015). Asymbiotic seed germination has been used for the multiplication of commercially important orchids, being an effective tool for orchid propagation, concerning conservation and reintroduction purposes (McKendrick 1995, 1996a and 1996b, Stenberg \& Kane 1998, Kauth et al. 2006, Stewart \& Kane 2006, Johnson \& Kane 2012, Wu et al. 2014).

In vitro seed germination studies can provide insights into in situ plant responses to environmental conditions and basic information on early plant growth and development. Several in vitro seed germination studies on $B$. purpurea can be found in the literature (Dutra et al. 2008, Johnson \& Kane 2012 and 2013). However, no information has been found about $B$. catenulata.

This study aimed at obtaining initial information on ornamental potential and influence of pollination type on seed viability of the B. catenulata orchid, in order to enable future preservation programs.

\section{MATERIAL AND METHODS}

Eight plants of B. catenulata were collected in December 2013, in Cachoeira da Rapadura (18 25'36.54”S; 52 56'57.23”W), in Costa Rica, Mato Grosso do Sul State, Brazil.

Plants were cultivated in plastic pots, using Plantmax $^{\circledR}$ - HT substrate, in a greenhouse, with daily irrigation. For the species identification procedures, the specimens were deposited in the herbarium of the Instituto de Botânica, in São Paulo, Brazil.

During the flowering stage of the collected plants, the height of the inflorescence stalk (measured from the base of the stalk to the topmost flower insertion point) and number of flowers/inflorescence were measured to calculate the mean number and standard deviation. Additionally, floral longevity was estimated by daily observation to obtain the date of the first anthesis and of the last senescent flower. Plants were monitored from July 1st to October 10th, in 2014.

To analyze the reproductive biology, ninety flowers in six inflorescences of six plants maintained in a greenhouse were used to carry out manual pollinations. After flower anthesis, self-pollination was carried out in thirty flowers. Cross-pollinations among flowers of the same individual (geitonogamy) and different individuals (xenogamy) were performed using thirty flowers for each pollination treatment. In all three treatments, pollinia were dislodged from the gynostemium by applying slight upward pressure to the bottom of the anther cap. After removal, pollinia were gently transferred into the stigmatic surface of the same (geitonogamy) or another (xenogamy) flower. Hand pollinated flowers were closely monitored for flower senescence, capsule development and capsule maturity.

To analyze the natural pollination, thirty flowers were maintained inside the greenhouse to 
test the spontaneous pollination without pollinators contact. Another plant with thirty flowers was maintained outside the greenhouse to verify open pollination with possible pollinator presence. In all previous cases, each group of ten flowers was considered a replication. The assessment of the pollination was carried out by counting the number of fruits obtained from the initial number of flowers.

After fruits were ripened, in vitro seed germination was carried out. Fruits were sterilized for twenty minutes in a solution of sodium hypochlorite ( $2 \%$ active Chlorine), followed by five minutes in $70 \%$ ethanol, and finally rinsed three times in sterile distilled water. Seeds were sown in Petri dishes containing $20 \mathrm{~mL}$ of Knudson $\mathrm{C}$ medium (Arditti \& Ernst 1993), supplemented with MS vitamins, $58.4 \mathrm{mM}$ of sucrose, $100 \mathrm{mg} \mathrm{L}^{-1}$ of myoinositol and $0 \mathrm{~g} \mathrm{~L}^{-1}$ or $2 \mathrm{~g} \mathrm{~L}^{-1}$ of activated charcoal, $\mathrm{pH}$ of $5.6 \pm 0.1$, and solidified with $5.0 \mathrm{~g} \mathrm{~L}^{-1}$ of agar $\left(\right.$ HiMedia $^{\circledR}$ ).

Cultures were maintained under a 16-hour photoperiod, with irradiance of $36 \mu \mathrm{mol} \mathrm{m} \mathrm{m}^{-2} \mathrm{~s}^{-1}$ provided by two fluorescent tubes of $20 \mathrm{~W}$ (Luz do Dia Especial, Osram, Brazil), and temperature of $27 \pm 2{ }^{\circ} \mathrm{C}$, in a growth room. After 45 days, seed germination data were obtained by counting protocorms and unfertile seeds using a light optical microscope. The seeds and protocorms counts were conducted in three sampling areas $(2.0 \mathrm{~cm}$ in diameter) of each Petri dish.

After vitroplants elongation, they were used to evaluate the acclimatization phase. Thirty vitroplants were individually placed in black plastic pots (7 cm height $\times 7 \mathrm{~cm}$ diameter) containing Plantmax ${ }^{\circledR}$ substrate. Pots were placed on benches and kept for 90 days in a greenhouse, with intermittent irrigation system comprised of micro-sprinklers activated by a timer, with two daily irrigation cycles of two minutes each. Plants received foliar fertilizer application $\left(\right.$ Nipokan $\left.^{\circledR}\right)$ at weekly intervals according to the manufacturer recommendation $(75 \mathrm{~mL} / 100 \mathrm{~L})$. After the acclimatization period, plants were evaluated in terms of survival percentage.

The pollination experiment was carried out using three replicates with ten flowers each. Due to the limitation in the number of collected plants supported by the SISBIO 22570-2 authorization, replicates were from the same plant containing at least 30 flowers. Thus, morphological and pollination data were used to calculate means and standard deviation. The in vitro experiment was performed using five replicates (plates) for each treatment, and it was arranged using a completely randomized design. Percentage data were arcsine transformed prior to the statistical analysis, and the Anova and Tukey test were used to compare the treatment $(\alpha=0.05)$, using the Sisvar software (Ferreira 2011).

\section{RESULTS AND DISCUSSION}

The inflorescence stalk mean length of $75.4 \pm 10.2 \mathrm{~cm}$, combined with the attractive and intense violet color, size and shape of flowers (Figure 1B), provides great potential for economic and ornamental exploitation of this species.

The $B$. catenulata flowering period extended from July to October, and racemes had $20.9 \pm 6.1$ flowers each. The total inflorescence longevity was $35 \pm 4$ days, considering the period between the first anthesis and the senescence of the last flower, resulting in a long lifetime of raceme and a long life-span flower, showing the ornamental potential of this species. Additionally, this could ensure better pollination success under scarce or uncertain pollinator visits, and consequently increase the time that each inflorescence is exposed to potential effective visitors to pollination (Flores-Palacios \& Garcia-Franco 2003, Castro et al. 2008).

Collected data show that $B$. catenulata presents successful fecundation, regardless of the pollen origin. Thus, all the pollination processes [geitonogamy, xenogamy, auto-pollination and open pollination (outside greenhouse)] resulted in fruit formation, and also in viable seeds. However, when flowers were protected against pollinator visits or spontaneous pollination (inside greenhouse), neither fruits and consequently nor seeds were detected (Table 1). These results indicate that $B$. catenulata is a self-compatible, pollinator-dependent species.

Most orchids are self-compatible (Van der Pijl \& Dodson 1966). However, spontaneous selfpollination tends to be avoided by the presence of special floral arrangements (Van der Pijl \& Dodson 1966, Catling \& Catling 1991). Manual pollination carried out under experimental conditions results in increased fruit production in many Orchidaceae species, if compared with populations in the natural environment (Pansarin 2003, Mickeliunas et al. 2006, Storti et al. 2011, Suetsugu 2015). Herbivory and fruits and seeds predation may negatively 
influence the reproductive success in orchids' natural habitat.

The fruit formation percentage in flowers submitted to open pollination (outside greenhouse) was considerably lower than in those submitted to manual pollination (Table 1), since, in many cases, pollination agents are a limiting factor. Similar results were found in other orchids genera. Smidt et al. (2006) and Silva-Pereira et al. (2007) studied the reproductive biology of four species from Chapada Diamantina, Bahia State, Brazil, and all were selfcompatible and pollinator-dependent. On the other hand, Micheneau et al. (2008) found that Jumellea stenophylla is clearly able to produce seeds in the

Table 1. Number of evaluated flowers, fruit formation (mean \pm standard deviation) percentage and in vitro seed germination, in relation to total seeds, from different pollination treatments carried out in Bletia catenulata Ruiz \& Pav. (Costa Rica, Mato Grosso do Sul State, Brazil, 2014).

\begin{tabular}{lccc}
\hline \multicolumn{1}{c}{ Pollination process } & Flowers (n) & Fruits (\%) & Germination (\%) \\
\hline Spontaneous self-pollination & 30 & 00.0 & - \\
Manual self-pollination & 30 & $86.7 \pm 12.5$ & $8.6 \mathrm{a}$ \\
Manual cross-pollination (geitonogamy) & 30 & $76.7 \pm 9.4$ & $4.5 \mathrm{a}$ \\
Manual cross-pollination (xenogamy) & 30 & $83.3 \pm 9.4$ & $2.0 \mathrm{ab}$ \\
Open pollination & 30 & $26.7 \pm 4.7$ & $0.9 \mathrm{~b}$ \\
\hline
\end{tabular}

Means followed by the same letter in the column do not differ by the Tukey test, at $5 \%$.
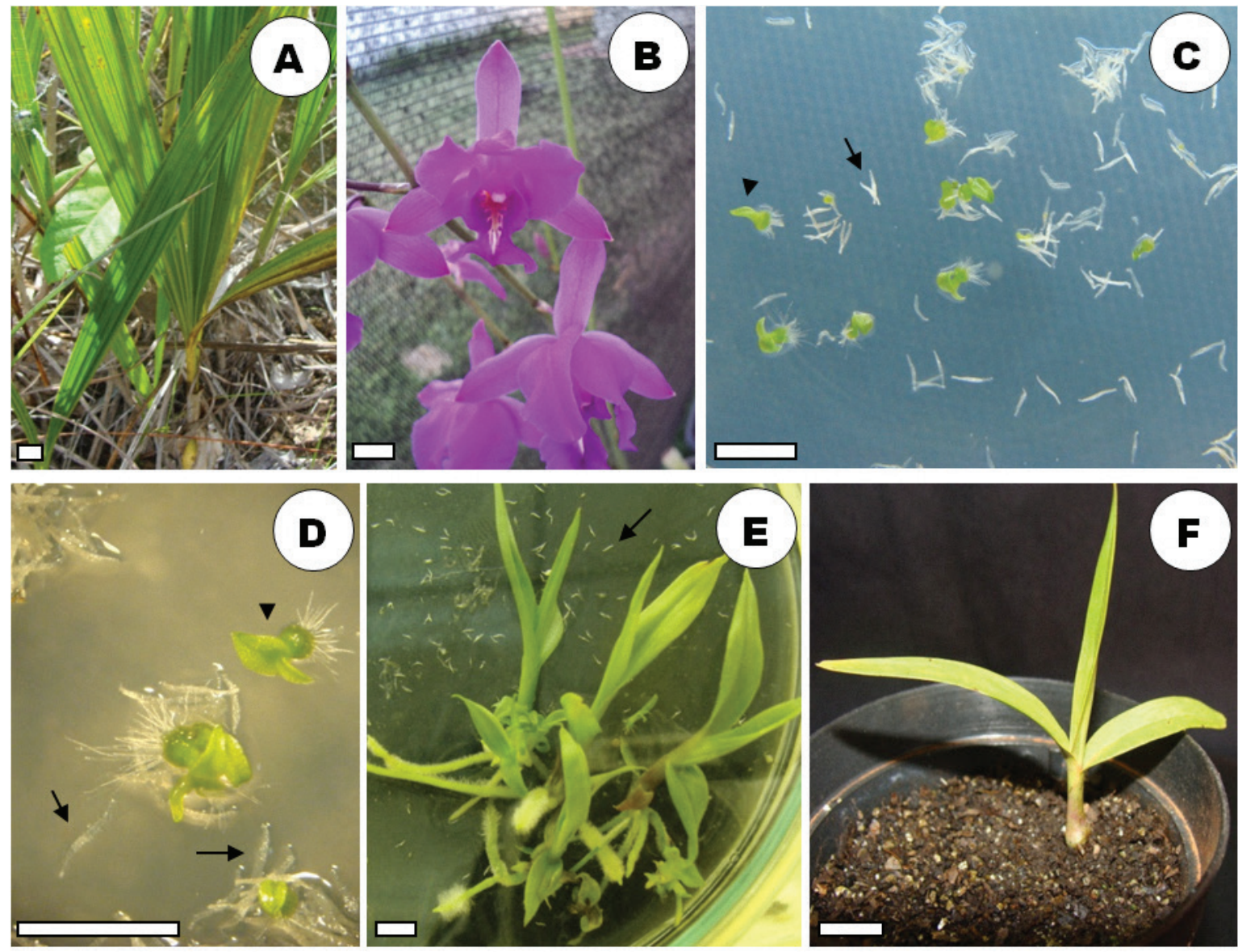

Figure 1. Bletia catenulata Ruiz \& Pav. in different cultivation stages: adult plant (A), flower after anthesis (B), vitroplants obtained from viable seeds (arrow heads) and unfertile seeds (arrows) on germination medium (C and D), elongated vitroplants and unfertile seeds (arrows) (E) and acclimatized vitroplant (F). Bar $=1.0 \mathrm{~cm}$ (Costa Rica, Mato Grosso do Sul State, Brazil, 2014). 
absence of pollinators, and the fruiting success of bagged flowers reached $66.7 \%$.

Seed viability tests showed that the germination rate was low in all types of obtained fruits (Table 1). These low germination values can be attributed to the high percentage of seeds lacking embryos present in the fruits (Figures 1C, 1D, 1E), always higher than $90 \%$.

The proportion of seeds containing viable embryos is critical to the ongoing maintenance of orchid population (Alexander et al. 2010). Bowles \& Jacobs (2002) showed that outcrossing by hand pollination produced higher percentage of viable seeds than with natural pollination in the Platanthera leucophaea orchid. According to Borba \& Braga (2003), the lower percentage of viable seeds from autogamous and geitonogamic pollinations in Pseudolaelia corcovadensis populations indicates the occurrence of endogamic depression in the early stages of development (embryo abortion). That was also frequently observed in other orchids from the Laeliinae subtribe (Stort \& Galdino 1984, Matias et al. 1996), or even in other orchids groups (Catling 1982, Borba et al. 2001), and seems to be widely distributed in the family.

The endogamic depression observed in $P$. corcovadensis is usually found in predominantly allogamous plant populations (Wiens et al. 1987, Husband \& Schemske 1996, Byers \& Waller 1999). Here, despite the intense presence of unviable seeds or infertile ovules, higher germination percentages were obtained by self-pollination and geitonogamy originated seeds. So, the occurrence of endogamic depression in B. catenulata is an unclear phenomenon and requires additional research.

The absence of fruits in the spontaneous self-pollination treatment (Table 1), when flower was spatially isolated from insects, showed that the pollinator presence is absolutely necessary for the $B$. catenulata sexual reproduction. Broughtonia lindenii, another species belonging to the Laeliinae subtribe, is pollinator-dependent and self-compatible (Vale et al. 2011). This reproductive combination of traits is broadly reported among nectarless tropical orchids, especially among the Laeliinae (Smidt et al. 2006). Although some orchid species are known to be self-incompatible, many are self-compatible and show varying levels of natural self-pollination or autogamy (Weston et al. 2005). Obligated autogamy is found in a few species (e.g. Orthoceras strictum), presumably as an adaptational response to scarcity or absence of pollinators. Completely autogamous species tend to produce smaller, less attractive/ colorful flowers than closely related outcrossers. This difference may be an evolutionary response to the loss of selective pressure for pollinator attraction. Conversely, we found that $B$. catenulata has characteristics of a pollinator-dependent species, such as relatively big, intense purple-colored flowers (Figure 1B). Thus, manual pollination can enhance propagation and preservation efforts.

Vitroplants resulting from protocorms (Figures 1C, 1D) showed good growth and development during the in vitro phase (Figure 1E). The acclimatization process was successful for $55 \%$ of the vitroplants (Figure $1 \mathrm{~F}$ ), and did not differ between treatments. Thus, the vitroplants acclimatization capacity is not dependent on the pollination type.

Knowledge on the reproductive biology of Bletia catenulata is important for in situ preservation programs which attempt to develop pollination strategies to enhance propagation success in areas where the species presents reduced number of plants. Furthermore, the commercial exploitation using manual pollination and in vitro seed germination could reduce the ongoing pressure originating from predatory collections of $B$. catenulata native plants.

\section{CONCLUSIONS}

1. Manual pollination increases the number of fruits and consequently the seed production, in relation to natural pollination.

2. Bletia catenulata seeds can be produced both by cross and self-pollination.

3. Bletia catenulata pollination is insect-dependent under natural conditions.

4. Fruits resulting from pollinated flowers offer viable seeds capable of producing normal plants by using the in vitro germination methodology.

\section{REFERENCES}

ALEXANDER, B. W. et al. Seed production and maturation of the western prairie fringed orchid. The Prairie Naturalist, Brookings, v. 42, n. 1/2, p. 55-60, 2010.

ARAÚJO, G. M. et al. Composição florística de veredas no município de Uberlândia, MG. Revista Brasileira de Botânica, São Paulo, v. 25, n. 4, p. 475-493, 2002. 
ARDITTI, J.; ERNST, R. Phalaenopsis. In: ARDITTI, J.; ERNST, R. Micropropagation of orchids. New York: Wiley, 1993. p. 467-520.

BARROS, F. de et al. Orchidaceae. 2015. Available at: <http://floradobrasil.jbrj.gov.br/jabot/floradobrasil/ FB19979>. Acess on: 21 Nov. 2015.

BATISTA, J. A. N.; BIANCHETTI, J. B.; PELLIZZARO, K. F. Orchidaceae da Reserva Ecológica do Guará, DF, Brasil. Acta Botanica Brasilica, Belo Horizonte, v. 19, n. 2, p. 221-232, 2005.

BELTRÁN-NAMBO, M. A. et al. Distribution and abundance of terrestrial orchids of the genus Bletia in sites with different degrees of disturbance, in the Cupatitzio Natural Reserve, México. International Journal of Biodiversity and Conservation, Nairobi, v. 4, n. 8, p. 316$325,2012$.

BORBA, B.; BRAGA, P. I. S. Biologia reprodutiva de Pseudolaelia corcovadensis (Orchidaceae): melitofilia e autocompatibilidade em uma Laeliinae basal. Revista Brasileira de Botânica, São Paulo, v. 26, n. 4, p. 541549, 2003.

BORBA, E. L.; SHEPHERD, G. J.; SEMIR, J. Selfincompatibility, inbreeding depression and crossing potential in five Pleurothallis (Orchidaceae) species. Annals of Botany, London, v. 88, n. 1, p. 89-99, 2001.

BOWLES, M. L.; JACOBS, K. Crossing effects on seed viability and experimental germination of the federal threatened Platanthera leucophaea (Orchidaceae). Rhodora, Lawrence, v. 104, n. 9, p. 14-30, 2002.

BROWN, P. M. Wild orchids of Florida. Gainesville: University of Florida Press, 2005.

BYERS, D. L.; WALLER, D. M. Do plant populations purge their genetic load?: Effects of population size and mating history on inbreeding depression. Annual Review of Ecology, Evolution and Systematics, Palo Alto, v. 30, n. 1 , p. 479-513, 1999.

CASTRO, S.; SILVEIRA P.; NAVARRO, L. Effect of pollination on floral longevity and costs of delaying fertilization in the out-crossing Polygala vayredae Costa (Polygalaceae). Annals of Botany, London, v. 102, n. 6, p. 1043-1048, 2008.

CATLING, P. M. Breeding systems of northeastern North American Spiranthes (Orchidaceae). Canadian Journal of Botany, Ottawa, v. 60, n. 12, p. 3017-3039, 1982.

CATLING, P. M.; CATLING, V. R. A synopsis of breeding systems and pollination in North American orchids. Lindleyana, West Palm Beach, v. 6, n. 3, p. 187-210, 1991.

CEPEMAR. Meio biótico. In: Estudo de impacto ambiental/ atividade de produção e escoamento de óleo e gás do Campo de Jubarte, Bacia de Campos. Vitória: Cepemar, 2004. p. 218-389.
CHEN, Y. et al. Asymbiotic seed germination and in vitro seedling development of Paphiopedilum spicerianum: an orchid with an extremely small population in China. Global Ecology and Conservation, Amsterdam, v. 3, n. 1, p. $367-378,2015$.

DODSON, C. H. The importance of the pollination in the evolution of the orchids of tropical America. American Orchid Society Bulletin, Cambridge, v. 31, n. 7, p. 525 534, 1962.

DRESSLER, R. L. Notes on Bletia (Orchidaceae). Brittonia, Bronx, v. 20, n. 2, p. 182-190, 1968.

DUTRA, D. et al. Asymbiotic seed germination, in vitro seedling development, and greenhouse acclimatization of the threatened terrestrial orchid Bletia purpurea. Plant Cell, Tissue and Organ Culture, London, v. 94, n. 1, p. 11-21, 2008.

FERREIRA, A. W. C.; LIMA, M. I. S.; PANSARIN, E. R. Orchidaceae in the central portion of São Paulo State, Brazil. Rodriguésia, Rio de Janeiro, v. 61, n. 2, p. 243259, 2010.

FERREIRA, D. F. Sisvar: a computer statistical analysis system. Ciência e Agrotecnologia, Lavras, v. 35, n. 6, p. 1039-1042, 2011.

FLORES-PALACIOS, A.; GARCIA-FRANCO, J. G. Effects of floral display and plant abundance on fruit production of Ryncholaelia glauca (Orchidaceae). Revista de Biologia Tropical, San Jose, v. 51, n. 1, p. 71-78, 2003.

HUSBAND, B. C.; SCHEMSKE, D. W. Evolution of the magnitude and timing of inbreeding depression in plants. Evolution, Lancaster, v. 50, n. 1, p. 54-70, 1996.

JOHNSON, T. R.; KANE, M. E. Differential germination and developmental responses of Bletia purpurea (Orchidaceae) to mannitol and sorbitol in the presence of sucrose and fructose. Journal of Plant Nutrition, New York, v. 36, n. 5, p. 702-716, 2013.

JOHNSON, T. R.; KANE, M. E. Effects of temperature and light on germination and early seedling development of the pine pink orchid (Bletia purpurea). Plant Species Biology, Kyoto, v. 27, n. 2, p. 174-179, 2012.

KAUTH, P. J.; VENDRAME, W. A.; KANE, M. E. In vitro seed culture and seedling development of Calopogon tuberosus. Plant Cell, Tissue and Organ Culture, London, v. 85, n. 1, p. 91-102, 2006.

MATIAS, L. Q.; BRAGA, P. I. S.; FREIRE, A. G. Biologia reprodutiva de Constantia cipoensis Porto \& Brade (Orchidaceae), endêmica da Serra do Cipó, Minas Gerais. Revista Brasileira de Botânica, São Paulo, v. 19, n. 1, p. 119-125, 1996.

MCKENDRICK, S. L. The effects of fertilizer and root competition on seedlings of Orchis morio and Dactylorhiza 
fuchsii in chalk and clay soil. New Phytologist, London, v. 134 , n. 2, p. 335-342, 1996 a.

MCKENDRICK, S. L. The effects of herbivory and vegetation on laboratory-raised Dactylorhiza praetermissa (Orchidaceae) planted into grassland in southern England. Biological Conservation, Essex, v. 73, n. 3, p. 215-220, 1995.

MCKENDRICK, S. L. The effects of shade on seedlings of Orchis morio and Dactylorhiza fuchsii in chalk and clay soil. New Phytologist, London, v. 134, n. 2, p. 343352, 1996b.

MICHENEAU, C. et al. Auto-pollination in a long-spurred endemic orchid (Jumellea stenophylla) on Reunion Island (Mascarene Archipelago, Indian Ocean). Plant Systematics and Evolution, Amsterdam, v. 272, n. 1, p. 11-22, 2008.

MICKELIUNAS, L.; PANSARIN, E. R.; SAZIMA, M. Biologia floral, melitofilia e influência de besouros Curculionidae no sucesso reprodutivo de Grobya amherstiae Lindl. (Orchidaceae: Cyrtopodiinae). Revista Brasileira de Botânica, São Paulo, v. 29, n. 2, p. 251-258, 2006.

PANSARIN, E.R. Biologia reprodutiva e polinização em Epidendrum paniculatum Ruiz \& Pavón (Orchidaceae). Revista Brasileira de Botânica, São Paulo, v. 26, n. 1, p. 203-211, 2003.

SCHININI, A. Orquídeas nativas del Paraguay. Rojasiana, San Lorenzo, v. 9, n. 1-2, p. 11-316, 2010.

SILVA, M. F. F. et al. Inventário da família Orchidaceae na Amazônia brasileira: parte I. Acta Botanica Brasilica, Belo Horizonte, v. 9, n. 1, p. 163-175, 1995.

SILVA-PEREIRA, V.; SMIDT, E. D. C.; BORBA, E. L. Isolation mechanisms between two sympatric Sophronitis (Orchidaceae) species endemic to Northeastern Brazil. Plant Systematics and Evolution, Amsterdam, v. 269, n. 3-4, p. 171-182, 2007.

SMIDT, E. C.; SILVA-PEREIRA, V.; BORBA, E. L. Reproductive biology of two Cattleya (Orchidaceae) species endemic to North-eastern Brazil. Plant Species Biology, Kyoto, v. 21, n. 2, p. 85-91, 2006.

STENBERG, M. L.; KANE, M. E. In vitro seed germination and greenhouse cultivation of Encyclia boothiana var. erythronioides, an endangered Florida orchid. Lindleyana, West Palm Beach, v. 13, n. 2, p. 101112, 1998.

STEWART, S. L.; KANE, M. E. Asymbiotic seed germination and in vitro seedling development of Habenaria macroceratitis (Orchidaceae), a rare Florida terrestrial orchid. Plant Cell, Tissue and Organ Culture, London, v. 86, n. 2, p. 147-158, 2006.

STORT, M. N. S. Cruzamentos artificiais envolvendo espécies do gênero Cattleya, subgêneros Monophyllae e Cattleya (Orchidaceae). Ciência e Cultura, São Paulo, v. 35 , n. 10, p. 1481-1486, 1983.

STORT, M. N. S. Fertilidade de cruzamentos e relação filogenética entre algumas espécies do gênero Cattleya Lindl. (Orchidaceae). Revista Brasileira de Botânica, São Paulo, v. 9, n. 1, p. 69-73, 1986.

STORT, M. N. S.; GALDINO, G. L. Self- and crosspollination in some species of the genus Laelia Lindl. (Orchidaceae). Revista Brasileira de Genética, Ribeirão Preto, v. 7, n. 4, p. 671-676, 1984.

STORTI, E. F.; BRAGA, P. I. S.; STORTI FILHO, A. Biologia reprodutiva de Cattleya eldorado, uma espécie de Orchidaceae das campinas amazônicas. Acta Amazonica, Manaus, v. 41, n. 3, p. 361-368, 2011.

SUETSUGU, K. Autonomous self-pollination in the nectarless orchid Pogonia minor. Plant Species Biology, Kyoto, v. 30, n. 1, p. 37-41, 2015.

SUZUKI, R. M. et al. Asymbiotic seed germination and in vitro seedling development of the threatened orchid Hoffmannseggella cinnabarina. In Vitro Cellular and Developmental Biology Plant, Wallingford, v. 48, n. 5, p. 500-511, 2012.

SWARTS, N. D.; DIXON, K. W. Terrestrial orchid conservation in the age of extinction. Annals of Botany, London, v. 104, n. 3, p. 543-556, 2009.

VALE, A. et al. Breeding system and factors limiting fruit production in the nectarless orchid Broughtonia lindenii. Plant Biology, Stuttgart, v. 13, suppl. 1, p. 51-61, 2011.

VAN DER CINGEL, N. A. An atlas of orchid pollination: America, Africa, Asia and Australia. Rotterdam: A. A. Balkema Publishers, 2001.

VAN DER PIJL, L.; DODSON, C. H. Orchid flowers: their pollination and evolution. Miami: University of Miami Press, 1966.

VÁSQUEZ, R.; IBISCH, P. L.; GERKMANN, B. Diversity of Bolivian Orchidaceae: a challenge for taxonomic, floristic and conservation research. Organisms Diversity and Evolution, Berlin, v. 3, suppl. 4, p. 93-102, 2003.

WESTON, P. H.; PERKINS, A. J.; ENTWISLE, T. J. More than symbioses: orchid ecology, with examples from the Sydney Region. Cunninghamia, Sydney, v. 9, n. 1, p. 1-15, 2005.

WIENS, D. et al. Reproductive success, spontaneous embryo abortion, and genetic load in flowering plants. Oecologia, Berlin, v. 71, n. 4, p. 501-509, 1987.

$\mathrm{WU}, \mathrm{K}$. et al. In vitro propagation and reintroduction of the endangered Renanthera imschootiana Rolfe. Plos One, San Francisco, v. 9, n. 10, p. 1-12, 2014. 